\title{
Good Corporate Governance (Gcg) Integration and Credit Restructuring and Its Impact on Conventional BPR Business Performance in Sidoarjo
}

\author{
$1^{\text {st }}$ Sumartik \\ Economic of Department \\ Muhammadiyah University of Sidoarjo \\ JL. Majapahit 666B Sidoarjo \\ sumartik@umsida.ac.id
}

\author{
$2^{\text {nd }}$ Misti hariasih \\ Muhammadiyah University of Sidoarjo \\ JL. Majapahit 666B Sidoarjo \\ Indonesia
}

\author{
$3^{\text {rd }}$ Lilik Indayani \\ Muhammadiyah University of Sidoarjo \\ JL. Majapahit 666B Sidoarjo \\ Indoenesia
}

\begin{abstract}
Conventional banks are banking financial institutions that function as intermediary institutions in the economic field that bring various impacts in the smooth implementation of the development of the city of Sidoarjo. Good governance and lending are one of BPR's main activities as an intermediary institution. Hot mud overflow. Lapindo in Sidoarjo, East Java, which has occurred since May 29, 2006 has given the banking worl especially ConventionalBanks in Sidoarjo, namely the inability to pay customers due to loss of jobs and livelihoods resulting in bad loans and credit restructuring processes. For the existence and continuity of business as well as enhancing the competitiveness of Conventional Banks, good corporate governance (GCG) integration and credit restructuring are carried out. The purpose of this study is to examine the effects of the integration of Good Corporate Governance (GCG) and credit restructuring on the business performance of Conventional Banks in Sidoarjo. This research is an explanatory research using 72 respondents, namely commissioners, main directors, compliance directors and managers of conventional banks in Sidoarjo. The variables used in this study are Managerial Ownership, Board of Commissioners, Audit Committee, Credit Responding, Credit Reconditioning, Credit Restructuring and Business Performance. The analytical tool used is the PLS Structural Equation Modeling (SEM) approach. The reason is because all variables in this study cannot be measured directly or, latent variables. The results of this study indicate that the integration of Good Corporate Governance and Credit Restructuring can be done either partially or simultaneously and is proven to have an effect on the business performance of Conventional Banks in Sidoarjo. Extensive and prolonged negative impacts until 2019, including
\end{abstract}

Keywords -Good Corporate Governance (GCG), Credit Restructuring, Business Performance

\section{INTRODUCTION}

In Indonesia, the conventional banking system, both commercial banks and people's credit banks is very good and always tries to improve the ability of financing for the economy of the community. Bank Credit Products increasingly diverse and increasing branch offices and services to the community in the micro and medium business sector. In the city of Sidoarjo the conventional People's Credit Bank is of great interest to the public in obtaining benefits from financial institutions both for consumptive activities, investment and working capital. On the other hand, the uncertainty of community livelihoods also colored the rate of return of borrowed funds resulting in a credit restructuring. Based on this it is necessary to integrate good corporate governance and credit restructuring at the BPR so that business performance is increasing.

Good corporate management is a system that regulates the relationship between the roles of the Board of Commissioners, the Board of Directors, shareholders and internal audit. Good corporate governance is also referred to as a transparent process of determining company goals, implementing and improving BPR performance. The GCG dimension consists of the Board of Commissioners, the Board of Directors, Shareholders and Internal Audit. In financial institutions, there is a lot of debate about the role of effective shareholders by implementing good corporate governance (Davis, 2002). As a governance mechanism, institutional investors are very important for bondholders (Bhojraj \& Sengupta, 2003; Bianchi \& Enriques, 2005; Fama \& Jensen, 1983; Grossman \& Hart, 1986; Jensen \& Meckling, 1976; López-Iturriaga, GarcíaMeca, \& Tejerina-Gaite, 2015; Shleifer \& Vishny, 1997). A strong shareholding makes it easier to monitor debt costs and risk reduction standards and corporate governance improve company performance in the long run (Boubakri \& Ghouma, 2010). T ata effective corporate governance can reduce the risk of default by monitoring managerial opportunistic behavior and affect the integrity of the financial accounting reports (Ramly, 2013). thus effectively reducing the cost of debt or reducing the risk of default (Ramly, 2013) and consequently more capital is increased.

In resolving bad loans, credit restructuring is carried out as an improvement effort made by the BPR to debtors 
who experience credit settlement problems. There are 3 dimensions of credit restructuring, namely: a. reschedulling, Aiming to change the payment schedule installments, extension of debt repayment period and interest arrears. b. reconditioningk, Aiming to changes in interest rates, the granting of waivers, additional collateral , c. restructuring, Activities aimed at diverting collateral / foreclosed properties (foreclosed assets) and write-offs / write-off .

Business performance is a form of achieving company goals through strategies in which there is intellectual capital and knowledge. The company's business performance can be achieved through corporate resources, branding, management capabilities, business strategies and knowledge transfer. (Sharabati, Shamari, Nour, Durra, \& Moghrabi, 2016) The problem faced by Conventional BPR in Sidoarjo is the number of complaints related to credit problems that require the handling of credit restructuring, all of which can be done if the governance of BPR is very good, especially from shareholders who will give up the amount of dividends as a reserve for business restructuring costs that will affect the performance business in particular is the achievement of capital and is influenced by the ability of resources in management and good business strategies to achieve business performance improvement. This research was conducted at the Sidoarjo People's Credit Bank incorporated in East Java PERBARINDO, among others:

\begin{tabular}{|c|c|c|}
\multicolumn{2}{|c}{ TABLE I . CONVENTIONAL BP DATA IN SIDOARJO } \\
\hline NO & BPR & ADDRESS \\
\hline 1 & PT BPR Buduran Delta Purnama & Jl Garuda 379 Sidoarjo \\
\hline 2 & PT BPR Pasar Bakti & Jl Raya Celep Sidoarjo \\
\hline
\end{tabular}

\begin{tabular}{|c|c|c|}
\hline NO & BPR & ADDRESS \\
\hline 3 & PT BPR Candisaka Arta & $\begin{array}{c}\text { J1 Raya Gelam Candi 8 } \\
\text { Sidoarjo }\end{array}$ \\
\hline \multicolumn{2}{|c|}{$\begin{array}{c}\text { award) } \\
\text { Source: secondary BPR data performing well 2018 in Sidoarjo (Infobank }\end{array}$} \\
\hline
\end{tabular}

The research hypotheses are as follows: a. there is a partial influence of good corporate governance (GCG) on the performance of conventional BPR businesses in Sidoarjo, b. There is an effect of partial credit restructuring integration on conventional BPR business performance in Sidoarjo, c. there is a partial influence of good corporate governance (GCG) and credit restructuring on the performance of conventional BPR businesses in Sidoarjo

\section{RESEARCH METHODS}

This research is a quantitative research with explanatory research, the population is all Conventional Rural Banks incorporated in PERBARINDO Sidoarjo which are performing well and received the 2018 infobank award, the sample is taken by sampling technique saturated based on a population of 72 respondents (shareholders, commissioners, main directors and compliance directors, managers, auditors and chief supervisors ). The instrument used was a questionnaire with interviews to strengthen the indicators contained in the questionnaire. The analysis tool uses SEM-PLS Wrap 5.0 software (inner and outer models) .

\section{RESULTS AND DISCUSSION}

\section{A. Data Quality Testing}

1. Validity and Reliability Test

Validity test based on the results obtained AVE (Average Variance Extraced) value greater than 0.5.

TABLE II. RESULTS FOR AVE

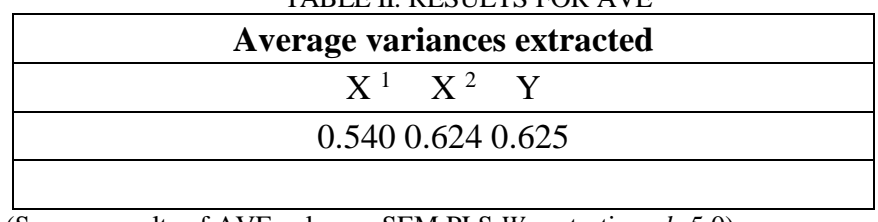

(Source, results of AVE value on SEM PLS Wrap testing pls 5.0)

Based on the table above the AVE value in the Good Corporate Governance (X1) variable is 0.540 , credit restructuring is 0.624 and Business performance is 0.625 . The three variables are said to be valid because they have an Average Variance Extraced (AVE) value of more than 0.5 .

Reliabilitas test is determined by the internal Consitency Reliability to see Composite Reiability whose value must be greater than 0.7 .

TABLE III. VALUE COMPOSITE RELIABILITY

\begin{tabular}{|lll|}
\hline \multicolumn{3}{|c|}{ Composite reliability coefficients } \\
\hline GCG & RK & BP \\
\hline 0854 & 0833 & 0892 \\
\hline
\end{tabular}

According to the table above, the value of composite reliability variable good corporate governance (X1) is 0 . 854 , restructured loans (X2) is 0.833 , business performance (X3) is 0.892 , which is all of the value is more substantial than 0.7 which means the value of data from variables $\mathrm{X} 1, \mathrm{X} 2$, and $\mathrm{Y}$ have good reliability or it can be said that the values of both independent and dependent variables are reliable.
2. Inner Model Testing (Structural Model)

Structural model testing is used to determine the magnitude of the effect, it can be seen in the value of Rsquares on the $\mathrm{Y}$ variable in this study. Effect sizes can be grouped into 3 categories: weak (0.02), medium (0.15) and large (0.35). 
TABLE IV. VALUES OF R-SQUARED COEFFICIENTS

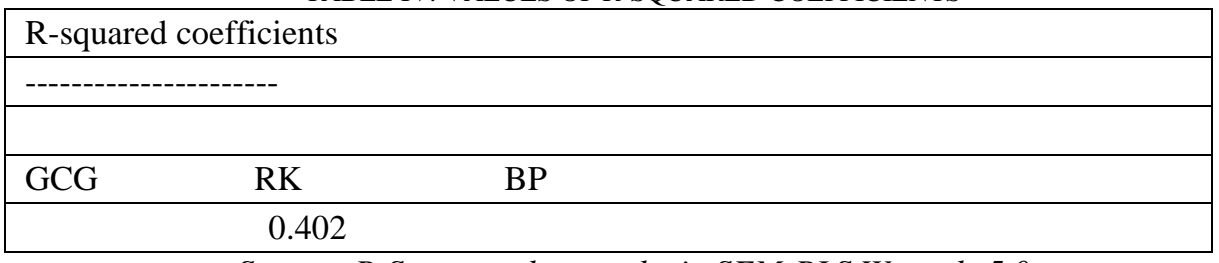

Source: $R$-Square value results in SEM-PLS Warppls 5.0

From the above table in the know value at variab el Business performance (Y) of 0.402 , or $40.2 \%$, which means that the influence of good corporate governance (X1), restructured loans (X2) tarhadap Business Performance (Y) can be said to have influence large because the value is more than 0,35 .

\begin{tabular}{|c|c|c|c|}
\hline \multicolumn{4}{|c|}{ Path coefficients } \\
\hline \multicolumn{4}{|c|}{----------------- } \\
\hline & GCG & $\mathrm{BP}$ & GCG \\
\hline \multicolumn{4}{|l|}{$\mathrm{CR}$} \\
\hline $\mathrm{BP}$ & $0.453 \quad 0.233$ & & \\
\hline
\end{tabular}

From the above table in the know value the influence of GCG at variab el Business performance (Y) of 0.453 or $45,3 \%$, while the value of the magnitude of the effect of debt restructuring (X2) tarhadap Business Performance (Y) of 0233 or $23.3 \%$.

B. Hypothesis testing

The hypothesis is accepted if the value of $p<0.10$. And to see the magnitude of the level of significance by way of seeing the value of $\mathrm{P}$-values at the output. While the beta coefficient $(\beta)$ is a value that shows the amount of influence between the variables studied.

1. To see the magnitude of the effect is partially variable $X 1$ to $Y$ is equal to :

$$
\begin{aligned}
& =\text { direct effect } \mathrm{X} 1 \text { on } \mathrm{Y} \\
& =0,453 \text { or } 45.3 \%
\end{aligned}
$$

2. To see the amount of influence partially the $X 2$ variable on $Y$ is equal to:
$=$ direct effect $\mathrm{X} 2$ on $\mathrm{Y}$

$=0,233$ or $23,3 \%$

3. To see the magnitude of the simultaneous influence of variable $X i, X 2$ on $Y$ is equal to:

$=$ total direct effect $\mathrm{X} 1$ against $\mathrm{Y}+$ total direct effect $\mathrm{X} 2$ against $\mathrm{Y}$

$=0,453+0.233$

$=0.686$ or $68.6 \%$

From the calculation results above, it is obtained that the variable of good corporate governance has a partial effect on business performance. Loan restructuring variable partially influences business performance. Good corporate governance and credit restructuring variables simultaneously affect the business performance .

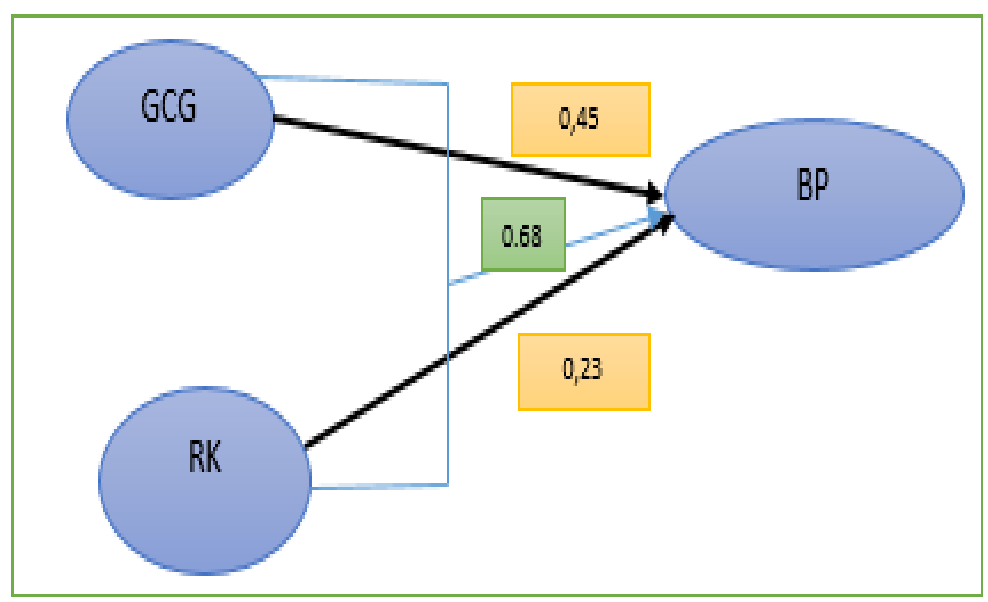

Fig. 1. Framework For Sem Pls Wrappls 5.0 Analysis Results Processed

\section{Discussion}

- First hypothesis. Good corporate governance variables partially affect Business performance. At the Conventional People's Credit Bank in Sidoarjo, good banking governance is needed, increasing the complexity of rural bank activities in Sidoarjo requires high competence to mitigate the risk of business activities. In order to improve bank 
performance, protect stakeholder interests and improve compliance with laws, good governance is required including management's seriousness in applying the principles of openness, accountability, responsibility, independence, fairness and prudence in managing BPR.

- Second Hypothesis. Loan restructuring variable partially influences business performance. In people's credit banks the ability to increase the number of credit debit trays by providing soft loans to debtors and MSME actors always carries the risk of uncertainty in returning credit, one of the efforts to improve the performance of conventional rural credit banks in Sidoarjo is by providing respite time for payment by credit restructuring. either rescheduling or discounting fines or discounting credit interest.

- Third Hypothesis. Good corporate governance and credit restructuring variables simultaneously affect the business performance . Good banking governance and credit restructuring can improve banking business performance if all directors are able to carry out their duties properly, there is no credit manipulation, loans are given prudently and are not affected by conflicting interests. The level of competence of leaders and employees also colors the knowledge sharing process in Sidoarjo Conventional Rural Banks so that they can provide good business strategies.

\section{CONCLUSION}

Good corporate governance Business partial effect on performance. Credit restructuring variable partially influences business performance. Good corporate governance and credit restructuring variables simultaneously affect the business performance. Banking governance activities also influence the level of competency of directors and employees so that prudent credit can occur. Allowance for payment so that there are no problematic customers can be given credit restructuring and all of them have an impact on the company's business performance, especially Conventional Rural Banks in Sidoarjo.

\section{ACKNOWLEDGMENT}

For this article, we would like to thank the commissioners, directors, managers, auditors at the Sidoarjo People's Credit Bank and the Muhammadiyah University of Sidoarjo.

\section{REFERENCES}

[1] Bhojraj, S., \& Sengupta, P. (2003). Effect of Corporate Governance on Bond Ratings and Yields: The Role of Institutional Investors and Outside Directors. Journal of Business, 76(3), 455-475. https://doi.org/10.1086/344114

[2] Bianchi, M., \& Enriques, L. (2005). Corporate governance in Italy after the 1998 reform: What role for institutional investors? Corporate Ownership and Control, 2(4), 11-31. https://doi.org/10.22495/cocv2i4p1

[3] Boubakri, N., \& Ghouma, H. (2010). Control/ownership structure, creditor rights protection, and the cost of debt financing: International evidence. Journal of Banking and Finance, 34(10), 2481-2499. https://doi.org/10.1016/j.jbankfin.2010.04.006

[4] Davis, E. P. (2002). Institutional investors and corporate governance. Economic Systems, 26(3), 203-229. https://doi.org/10.1007/978-4-431-30920-8_4

[5] Fama, E. F., \& Jensen, M. C. (1983). Separation of Ownership and Control Eugene. Journal of Law and Economics, 26(2), 301-325. Retrieved from http://dialnet.unirioja.es/descarga/articulo/3728530.pdf

[6] Grossman, S. J., \& Hart, O. D. (1986). The Costs and Benefits of Ownership: A Theory of Vertical and Lateral Integration. Journal of Political Economy, 94(4), 691-719. https://doi.org/10.1086/261404

[7] Jensen, M. C., \& Meckling, W. H. (1976). THEORY OF THE FIRM: MANAGERIAL BEHAVIOR, AGENCY COSTS AND OWNERSHIP STRUCTURE. Journal of Financial Economics, (3), 305-360. https://doi.org/10.1177/0018726718812602

[8] López-Iturriaga, F., García-Meca, E., \& Tejerina-Gaite, F. (2015). Institutional directors and board compensation: Spanish evidence. BRQ Business Research Quarterly, 18(3), 161-173. https://doi.org/10.1016/j.brq.2014.07.003

[9] Ramly, Z. (2013). Corporate Governance , Shareholder Monitoring and Cost of Debt in Malaysia. International Journal of Social, Management, Economics and Business Engineering, 7(4), 494-505. Retrieved from https://pdfs.semanticscholar.org/0b7f/d8a86619bd8b88385463c b2a570abc233577.pdf

[10] Sharabati, A. A., Shamari, N. S., Nour, A.-N. I., Durra, A.-B. I., \& Moghrabi, K. M. (2016). The impact of intellectual capital on business performance in Kuwaiti telecommunication industry. International J. Business Performance Management, 17(4), 428-446.

[11] Shleifer, A., \& Vishny, R. W. (1997). Surveycorpgov.Pdf. The Journal Of Finance, 52(2), 737-783. 